\title{
Profits, harvests or public revenue? Divergent interests and guano fertiliser struggles in the Cape Colony; c. 1872-1910
}

\author{
Hendrik Snyders*
}

\begin{abstract}
During the first 50 years of its existence, the Cape guano trade was controlled by entrepreneurs who were profit and export orientated. They used their control over certain offshore islands through long-term exploitation leases to fix prices and to manipulate supply to their maximum advantage. Internal divisions, limited financial means and a lack of sophisticated fertiliser knowledge as well as weak farmer organisation, prevented Cape farmers from reversing this situation. Faced with declining soil quality, noxious weeds and decreasing harvests that threatened to scupper their livelihoods, Cape farmers made skilful use of protest, petitioning and pressurising their public representatives and finally succeeded in securing government intervention and access to cheaper and subsidised guano. Fearing their exclusion from the hitherto lucrative trade, guanopreneurs and their political allies resisted this move strongly. The ensuing battle for control of the Cape guano fertiliser market not only saw the last attempts by entrepreneurs to resist state appropriation of the product, but also inadvertently gave guano a small role in the unfolding of political events in the years leading up to the establishment the Union of South Africa.
\end{abstract}

Key words: guano, fertiliser, farmers, Cape Colony, entrepreneur

\section{Opsomming}

Tydens die eerste 50 jaar van sy bestaan was die Kaapse ghwano-handel in die hande van wins- en uitvoergedrewe entrepeneurs. Dié het deur middel van langtermyn eksploitasie-kontrakte beheer oor nabygeleë eilande uitgeoefen, wat hulle in staat gestel het om pryse vas te stel en die beskikbaarheid van ghwano vir hul eie gewin te reguleer. Onderlinge verdeeldheid, beperkte finansies, onkunde oor bemesting, sowel

\footnotetext{
${ }^{*}$ The author is a PhD (History) graduate of the University of Stellenbosch and currently works as the Heritage Manager at the South African Rugby Union. His current research and publication focus is the international guano trade in general and early Cape trade in particular. He has published various articles on sports history (rugby union; rugby league, rodeo and Australian football) as well as on war and memory in peer reviewed academic journals.
}

\section{How to cite this article:}

H. Snyders, "Profits, harvests or public revenue? Divergent interests and guano fertiliser struggles in the Cape Colony; c. 1872-1910", Historia 60, 2, November 2015, pp 160-184. http://dx.doi.org/10.17159/2309-8392/2015/v60n2a8

\section{Copyright:}

(C) 2015. The Author(s). Published under a Creative Commons Attribution License. 
as gebrekkige samewerking, het aanvanklik gekoördineerde optrede deur die Kaapse boere in die wiele gery. Met die grondgehalte wat egter algaande verswak het, skadelike onkruid en kwynende oeste wat hul brood en botter bedreig het, het Kaapse boere deur middel van die vernuftige gebruik van protes, petisies en druk op hul openbare verteenwoordigers, uiteindelik daarin geslaag om die regering te noop om in te gryp, en sodoende toegang tot goedkoop, gesubsidieërde ghwano verkry. Die "ghwanopreneurs" en hul politieke bondgenote, wie se aandeel in dié winsgewende handel daardeur in gedrang gekom het, het dit heftig teengestaan. Die daaropvolgende stryd om beheer oor die Kaapse ghwano bemestingsmark was nie net tekenend van die entrepeneurs se laaste pogings om staatstoe-eiening van die produk te beveg nie, maar het ook 'n klein rolletjie aan ghwano toegeken in die politieke gebeure wat Suid-Afrika se Uniewording voorafgegaan het.

Sleutelwoorde: ghwano; bemesting; boere; Kaapkolonie; entrepreneur.

\section{Introduction}

The development of a culture of fertiliser-usage and concomitantly the existence of a significant fertiliser market was a late development in the economic history of the Cape Colony. As far back as 1800, William Duckitt, the Cape's first agricultural expert, upon observing a quantity of manure lying exposed to the atmosphere commented that such a situation was "on the whole not very desirable for a farm". ${ }^{1}$ This situation was not much different by the time the British took over political control of the Cape from the Dutch six years later. According to Jeffries, Commissary De Mist, the Dutch representative, handed over a colony that did not have a strong fertiliser tradition, and was struggling to achieve food security. ${ }^{2}$

These two factors, Van Zyl suggests, were not only indivisibly linked but also largely explained the persistent struggle of nineteenth-century Cape grain (wheat, barley and oats) farmers to produce an adequate surplus. ${ }^{3}$ Optimising available land use therefore became an early British priority. Ensuring greater food security and concomitantly commercialising Cape agriculture was, however, a process fraught with difficulties punctuated by the struggle of local farmers for access to cheap guano fertiliser (birds' dung) and that of local business men for zero price-control over the sale of the product from the mid-nineteenth to the early twentieth century. In addition to struggling against declining soil quality, weed infestation and a lack of

${ }^{1}$ C.A. Jurgens, "A Look into the Future", Journal of the Fertilizer Association of South Africa, 2, 1972, p 23.

${ }^{2}$ K.M. Jeffries (ed.), The Memorandum of Commissary J.A. de Mist, containing Recommendations for the Form and Administration of Government at the Cape of Good Hope, 1802 (Van Riebeeck Society, Cape Town, 1920).

${ }^{3}$ D. van Zyl, "Die Geskiedenis van die Graanbou in die Kaapkolonie, 1795-1826", Archives Year Book for South African History, 27 (Government Printer, Pretoria, 1968).

${ }^{4}$ R. Ross, "Emancipations and the Economy of the Cape Colony", p 132, available at < https://www.openacces.leidenuniv.nl/bitstream/1887/4235/1/1246876 067.pdf> (Accessed 20 September 2008). 
sufficient fertilisers to restore the fertility of the available land, they also had to contend with negative market forces such as low prices and competition from foreign imports. The biophysical environment therefore became a major player in the shaping not only of the history of Cape grain and wine cultivation but, also of the larger economic and political history of the colony. ${ }^{5}$

This article traces the battle between Cape farmers and merchants on the issue of free or subsidised guano against the background of various agricultural challenges such as declining soil quality, proliferation of noxious weeds and other issues of fertiliser supply.

\section{Geophysical challenges of nineteenth-century Cape farming}

A colonial government survey undertaken in 1840, three years before the beginning of the Cape guano (birds' dung) trade, to asses the quality of Crown land in the colony, indicated that an estimated 14 million hectares of the was "rocky, mountainous, sterile or inaccessible". This land needed some form of fertilisation. ${ }^{6}$ Furthermore, practically all productive farming land in the colony (which translated into 43 million acres or three-fifths of the available land), was already in the possession of private individuals. The remaining land, due to its location and the prevailing geotechnical conditions, was land that "nobody sought" 7 simply because of its unsuitability for both intensive agriculture and stock farming. ${ }^{8}$ Furthermore, the Cape Colony's Mediterranean-type climate has always been a landscape "susceptible to land degradation, perhaps even desertification". ${ }^{9}$

However, this does not mean that soil quality alone is a guarantee of agricultural success. Indeed, Fourie and Von Fintel, albeit in a different context, suggest that the possession of certain agricultural skills, especially in the field of viticulture, is equally important. Wheat farming for example, which "utilises more generic knowledge and farming skills, especially in the secondary production processes of flour and bread making", also has certain specific requirements. ${ }^{10}$ The majority of Cape farmers, however, lacked a sophisticated knowledge of both the

\footnotetext{
${ }^{5}$ M.A. Schnurr, "Cotton as a Calamitous Commodity: The Politics of Agricultural Failure in Natal and Zululand, 1844-1933", Departmental Paper, International Development Studies, (Dalhousie University, Halifax, 2000), p 3.

${ }^{6}$ A.J. Christopher, "Land Policy in Southern Africa during the Nineteenth Century", Zambezia, 2, 1, 1971, p 40.

${ }^{7}$ T. Kirk, 'The Cape Economy and the Expropriation of the Kat River Settlement, 1846-53", in S. Marks and A. Atmore (eds), Economy and Society in Pre-industrial South Africa (Longman, London, 1980), p 238.

${ }^{8}$ K. Brown, "Agriculture in the Natural World: Progressivism, Conservation and the State: The Case of the Cape Colony in the Late 19th and Early 20th Centuries", Kronos, 29, 2003, pp 109110.

${ }^{9}$ M.E. Meadows, "Soil Erosion in the Swartland, Western Cape Province, South Africa: Implications of Past and Present Policy and Practice", Environmental Science \& Policy 2 6, 1, February 2003, pp 17-28.

${ }^{10} \mathrm{~J}$. Fourie and D. von Fintel, "Settler Skills and Colonial Development", Working Paper No. 213, University of Stellenbosch and University of Utrecht, March 2011, p 15.
} 
efficacy and availability of fertilisers other than kraal manure, as is evident in the difficulty a local businessman, Thomas Ramsden, had to endure to profit from the sale of a load of guano which he collected from Malgas Island in Saldanha Bay in 1842.11 In addition, Eastern Cape farmer, John Centrelives Chase noted that compound manures were generally unknown and that most farmers continued to use kraal manure for dressing their agricultural land. ${ }^{12}$ These fairly representative observations contradict the assertion made by Robert Ross that farmers purchased guano with the compensation paid for freed slaves in an effort to achieve better productivity. ${ }^{13}$ Indeed, a formal Cape fertiliser market did not exist at the beginning of the 1840s.

The ability of soil, one of the "initial factor endowments", to produce highyielding harvests is influenced by factors such as drought, water and nutrients. Furthermore, crop yield is also influenced by plant disease, insects, and climatic conditions such as frost, flash floods and wind. The significant absence of any of the endowments, according to Fourie and Van Fintel, often lies at the heart of the economic underdevelopment of an area. ${ }^{14}$

By the middle of the nineteenth century, most agricultural produce (wheat, grain, wine, etc.) was primarily grown in the western districts of the Cape Colony, and agriculture dominated the economy to the tune of 78 percent (78\%) of the output. The pastoral economy, which was mostly located in the eastern districts, only accounted for 22 percent (22\%). In specific terms the wheat harvest of 1855 totalled nearly one million bushels; grain more than 700 000; and barley nearly half a million bushels. ${ }^{15}$ The bulk of this harvest was consumed domestically by the Cape population that totalled 267096 at the time. ${ }^{16}$ Cultivating wheat was particularly difficult in the lime soil of the Overberg district, in comparison to the sandy soil of the Swartland. ${ }^{17}$ Moreover, repeated and widespread droughts rendered only small pockets of the colony suitable for cultivation without irrigation.

According to Grove, southern Africa suffered three major and devastating droughts (1821 to $1823 ; 1845$ to 1857 ; and 1862 to 1863 ), all of which disrupted

${ }^{11}$ Cape Archives Repository (hereafter KAB), Colonial Office (hereafter CO), 4020: 133, Collector of Customs - Governor, 26 December 1844.

12 J.C. Chase, The Cape of Good Hope and the Eastern Province of Algoa Bay, with Statistics of the Colony (Pelham Richardson, London, 1842), p 150.

13 Ross, "Emancipations and the Economy of the Cape Colony", p 140.

${ }^{14}$ Fourie and Von Fintel, "Settler Skills and Colonial Development", p 1.

${ }^{15}$ R. Ross, "The Relative Importance of Exports and the Internal Market for the Agriculture of the Cape Colony, 1770-1855", Proceedings of the Symposium on the Quantification and Structure of the Import and Export and Long Distance Trade of Africa in the 19th Century (c. 1800-1913), St. Augustin, 3-6 January 1983, pp 248, 253.

16 G. Verhoef, L. Greyling and J. Mwamba, "Savings and Economic Growth: A Historical Analysis of the Relationship between Savings and Economic Growth in the Cape Colony Economy, 1850-1909", Munich Personal RePEc Archive (hereafter MPRA), 22 June 2013 at $<$ http://mpra.ub.uni-muenchen.de/47819/> (Accessed 1 June 2015).

17 J. Wilson, "Rural Revolution: Wheat, Wool and Politics in the Overberg", Contree, 31, April 1992, p 3. 
both the local economies and the social fabric of the affected societies. ${ }^{18}$ In addition, several less devastating, but equally disruptive calamities threatened the general livelihoods of the citizens of the Cape Colony. One notable instance was severe flooding and a drought in the summer of 1838 to 1839 that destroyed a significant percentage of the wheat crop in the Boland and the Swellendam/George wheat belt. This reduced the season's grain harvest dramatically. The wine industry closer to Cape Town was only saved because the calamity hit at the beginning of the main grape harvesting period. ${ }^{19}$ The 1846 drought on the other hand was not only "ferocious" and of biblical proportions but also left lasting impressions and images of "desiccation and death" on those who lived through it. ${ }^{20} \mathrm{~A}$ combination of these disasters during the period 1861 to 1864 , forced the Cape government to import 47 603 bushels of wheat; 269467 barrels of flour; 954 bushels of barley; and 3935 bushels of oats in order to feed the growing colonial population. ${ }^{21}$ At various times natural disasters in combination with factors such as intensive competition and high inflation and production costs conspired to push the Cape colonial economy into recession and "trying times". ${ }^{22}$

The soil erosion and the loss of valuable topsoil that inevitably followed calamities such as these led to the dispersal of seeds and the proliferation of weeds such as jointed cactus, burr weed and prickly pear over a wide area. This meant that farmers in both the western and eastern districts of the colony not only had to compete "with the residual grasses for control of the soils and available water supplies" but also had to deal with more noxious plants such as the poisonous "gifblaar" which further reduced the carrying capacity of the available land and threatened animal farming. In the absence of substantial and sophisticated scientific knowledge about weed management, farmers combined rotational grazing and periods of fallowing in an attempt to minimise the negative economic impact of this environmental problem. ${ }^{23}$ However, this did not always succeeded in mitigating the eroding effect of these constraining conditions on agricultural profits. ${ }^{24}$

\footnotetext{
${ }^{18}$ R. Grove, "Scottish Missionaries, Evangelical Discourses and the Origins of Conservation Thinking in Southern Africa, 1820-1900", Journal of Southern African Studies, 15, 2, January 1989, p 175.

${ }^{19} \mathrm{~N}$. Worden, "Adjusting to Emancipation: Freed Slaves and Farmers in the mid-NineteenthCentury South-Western Cape", in G. Wilmot,** J. Simons and M. Simons (eds), The Angry Divide: Social and Economic History of the Western Cape (David Phillip, Cape Town and Johannesburg, 1989), p 34.

20 Grove, "Scottish Missionaries", p 175.

${ }^{21}$ Official Publications of the Cape Colony (hereafter AMPT PUBS), CCP 2/2/1/2 C6: Printed Paper of the Legislative Council, Cape of Good Hope: Return specifying the quantities of wheat, flour, barley, and oats imported into this Colony from 1st January, 1861 to 31st December 1864, etc. (hereafter C6-1865).

22 A. Mabin, "The Underdevelopment of the Western Cape, 1850-1900", in Wilmot, Simons and Simons (eds), The Angry Divide, p 83.

${ }^{23}$ K. Brown, "Poisonous Plants, Pastoral Knowledge and Perceptions of Environmental Change in South Africa, c. 1880-1940", Environment and History, 13, 3, August, 2007, p 326.

${ }^{24}$ L. van Sittert, "The Seeds Blow about in Every Breeze: Noxious Weed Eradication in the Cape Colony, 1860-1909", Journal of Southern African Studies, 26, 4, December, 2000, p 662.
} 
Because of the challenges emanating from the geophysical environment and its debilitating effect on agricultural output, an acute need was strongly articulated for additional forms of fertilisation over and above the traditional use of kraal manure. At the South African International Exhibition (1855) held in Port Elizabeth, in response to J.W. Stroud's price-winning essay entitled "Agricultural Science and its Application to Conditions of the Colony", in which he strongly advocated the wider use of fertiliser in local agriculture, the awards committee noted: "We should like to have seen some samples of artificial manures, and were rather disappointed at finding none." 25 This remark was quite revealing because at the time a small number of Cape-based guano suppliers such as Stephan \& Co., Granger \& Co., De Pass, Spence \& Co. and Thomson, Watson \& Co., were already trading in the colony. Over the period 1843 to 1861, through a combination of strategic buy-outs and take-overs, they succeeded in establishing monopoly control over both the Namibian and Cape offshore islands from which guano was imported. ${ }^{26}$

\section{The evolution of the Cape guano market, 1843-1872}

With the beginning of the guano trade from the coast of Angra Pequena and a number of offshore islands within the Cape's territorial waters in 1843, the colonial government promulgated Ordinance 4 of 1845 (the so-called "Guano Ordinance") to ensure the orderly exploitation of the resource in the areas under its jurisdiction. As a result, it derived a significant income through the selling of loading licences at $£ 1$ per ton for shipping from the various territorial islands along the West Coast, False Bay and Algoa Bay between the years from 1843 to 1845. Under this dispensation, most islands including those in the Bay of Angra Pequena, were scraped down to the rock and the guano collected, at an estimated value of more than $£ 50000$, was exported to Europe and other parts of the world. ${ }^{27}$ This revenue became a critical source of additional income for the colonial authorities and was inter alia used to create new infrastructure. From 1854, onwards this "fortunate addition" to the coffers also assisted in financing the implementation of representative government in the face of imperial budget cuts for the governance of the Colony. ${ }^{28}$ Cape farmers and their agricultural needs featured nowhere in this equation.

Because of the finite and speculative nature of guano and the ensuing trade due to the migratory pattern of the guano birds (their seasonal departure and return to the islands) local businesses involved in guano collection were geared primarily towards servicing the Mauritian and European markets..$^{29}$ Not only were sales higher

\footnotetext{
${ }^{25}$ E. Rosenthal, "The Story of Fison Albatross in South Africa", Unpublished manuscript, 1955, p 5.

${ }^{26} \mathrm{KAB}, \mathrm{AMPT}$ PUBS, Cape of Good Hope: Report of the Select Committee (SC) on the Annexation of Ichaboe, A.11- 1861 (Saul Solomon \& Co., Cape Town): Testimony of R.P. Dobie, p 70.

${ }^{27}$ H. Snyders, "Stinky and Smelly but Profitable: The Cape Guano Trade, c. 1843-1910, PhD dissertation, University of Stellenbosch, 2011, p 83.

${ }^{28} \mathrm{KAB}$, CO 539, Treasury and Audit Office - Colonial Office: Statement of Revenue and Expenditure of the Colony of the Cape of Good Hope, 1845.

${ }^{29}$ E. Rosenthal, Stars and Stripes in Africa (National Books, Cape Town, 1968), p 65.
} 
in Mauritius than in Cape Town, but at a rate of 30s to 35s per ton, freight costs from Ichaboe to Mauritius, in comparison to Table Bay, were relatively cheap. In addition, at a potential net price of $£ 6.14 \mathrm{~s}$ per ton and a net gain of $18 \mathrm{~s} .10 \mathrm{~d}$ per ton, profits for exporting the fertiliser were far higher than selling guano locally. ${ }^{30}$ It was therefore hardly surprising that local firms such as De Pass, Spence \& Co., were unapologetic about their choice and displayed an attitude of wanting to have "nothing to do with the Cape Town market". ${ }^{31}$ This situation remained unchanged even after 1861, when the colonial authorities decided to lease out the exploitation of the various guano islands within their jurisdiction, such as the West Coast islands (Malgas, Jutten, Vondeling, Bird Island and Dassen Island) to private businessmen. As a result, domestic guano prices remained high with local farmers unable to afford full access to the popular natural fertiliser. This was in contrast with the situation in the American antebellum South, where businessmen were ignored and treated as secondary to the planting culture. ${ }^{32}$

As a result of the continued challenges posed by the colony's changing geophysical conditions and the increasing difficulties encountered by Cape farmers, those with a commercial orientation began to use both natural and chemical fertilisers which came onto the local market in the intervening years, in an attempt to revitalise the available land for planting and to offset some of the damage caused by natural disasters, declining soil quality and noxious weeds. Although it is difficult to reconstruct the details of domestic use of guano for this period because of the lack of customs records, one can use verbal evidence from farmers to demonstrate that a local guano market existed for both chemical and natural fertilisers. ${ }^{33}$ Among the small number of brands that were available to farmers were imported product labels such as De Pass Fertiliser, Framers Phosphate Powder and Lawes Fertiliser. ${ }^{34}$ These were mainly supplied by businesses such as Stephan Brothers and De Pass, Spence \& Co., who were among the main guano island leaseholders.

The opening of the Kimberley diamond fields from 1867 onwards, and the new mining communities that arose, created new market opportunities for businessmen and commercial farmers alike, especially those involved in the production and provision of staples like wheat and other commodities such as wine. This meant that business enterprises based in the Western and the Eastern Cape benefited. However, in no time the available opportunities generated conflict between commodity merchants on the one hand and farmers on the other. At the root of the tension were attempts by various traders, with the support of their parliamentary representatives

${ }^{30}$ KAB, AMPT PUB, SC. A.30 -'99: Cape of Good Hope: Report of the Select Committee on the Workings of the Guano Islands, Testimony of Charles Curry, p 8.

${ }^{31} \mathrm{KAB}$, AMPT PUB, SC. A. 11-'61: Testimony of T. Boyce, p 12.

${ }^{32}$ L. Schwelkart, "Antebellum Southern Bankers: Origins and Mobility", Business and Economic History, 14, 1985, p 79.

${ }^{33} \mathrm{~L}$. van Sittert, "Historical Reconstruction of Guano Production on the Namibian Islands 1843-1895", South African Journal of Science, 99, 2003, p 14.

${ }^{34} \mathrm{KAB}$, AMPT PUBS, CCP A.39, Printed Paper of the House of Assembly, Cape of Good Hope: Report of the Select Committee on the Guano Islands, October 1899 (hereafter A.39-'99 Guano Islands), pp 25-26. 
under the cloak of "free trade" and "cheap bread", to sell cheap foreign wheat as the surest way to maximise profitability.

According to Giliomee, when faced with a direct threat to their livelihood, the farming communities of the principal wheat-growing districts of the Western Cape ditched their traditional disinterest in parliamentary politics and exchanged it for a more activist orientation - demanding tariff protection to ensure a fair return on capital investment. ${ }^{35}$ Given the geophysical challenges under which farmers laboured, they had very few other means of averting the potential bankruptcy posed by cheap wheat imports. As a direct result, in 1869 commercial wheat farmers based in the Stellenbosch, Malmesbury and Paarl districts launched the Malmesbury Protection Committee (MPC) with the objective to secure election of sympathetic parliamentary candidates into the legislature.

Since the MPC was only representative of the wheat farmers of the Western Cape districts and excluded wine and stock farmers as well as those in the Eastern districts, the organisation had little real and immediate influence. Its key objectives of fielding its own parliamentary candidates could therefore not be realised immediately. However, their endeavours served as an important example for others with similar concerns.

In contrast to the activism of the Western districts which was undoubtedly bolstered by having direct access to a larger number of public representatives in the colonial legislature in Cape Town and a well-organised business network, the Eastern Cape's influence over the colonial government was extremely limited. As capitalists, Eastern-based businessmen and farmers undoubtedly shared the same belief in material progress, industriousness, business efficiency and private enterprise, as well as a bias for surplus as a source of income instead of subsistence. ${ }^{36}$ The existence of internal divisions within their ranks in the face of a more united and organised Western front arguably retarded the economic advancement of the region and assisted Cape Town in consolidating itself as the main coastal entrepot. ${ }^{37}$

Although 1870 was a good year for the wheat harvest which increased by nearly 50 percent to an estimated 1,5 million bushels as a result of a larger area being cultivated, the potential benefits of this increased yield was almost immediately nullified by low prices. Cape grain farmers had every right to complain that "the ruling prices did not repay the corn farmer for his trouble and outlay". ${ }^{38}$ The situation in the wine industry during the early years of the 1870 s was no different.

Recurring droughts and disputes with wine merchants over pricing continued to beset the sector throughout the decade. By 1878, the potential benefit of a wine

\footnotetext{
${ }^{35} \mathrm{H}$. Giliomee, "Aspects of the Rise of Afrikaner Capital and Afrikaner Nationalism in the Western Cape, 1870-1915", in Wilmot, Simons and Simons (eds), The Angry Divide, p 65.

${ }^{36}$ Kirk, "The Cape Economy and the Expropriation of the Kat River Settlement", p 237.

${ }^{37}$ Mabin, "The Underdevelopment of the Western Cape", p 84.

${ }^{38}$ Giliomee, "Aspects of the Rise of Afrikaner Capital", p 65.
} 
surplus was wiped out when prices nose-dived. To aggravate matters, the newly installed responsible government under Gordon Sprigg, in its first legislative act, saw fit to promulgate a new excise duty on Cape spirits. Unsurprisingly, a sense of gloom and deep feelings of anger descended upon the sector. ${ }^{39}$ Although this act mirrored other equally arbitrary official acts such as the 1869 appropriation of guano income for government purposes, this measure pushed matters to the breaking point for wine farmers, who together with their brethren in the grain sector, were the primary clients of the growing guano fertiliser trade. ${ }^{40}$ They therefore established the ZuidAfrikaansche Boeren Beschermings Vereeniging (BBV) or the South African Farmers' Protection Association (SAFPA) to fight the excise duty.

Over time, SAFPA broadened its objectives to include the protection of the political and economic interests of all farmers, the advancement of general farming interests and the promotion of farming entrepreneurship. ${ }^{41}$ Like the MPC earlier, SAFPA adopted a strategy of supporting suitable political representatives and opposed "legislation oppressive to the farming community". 42 These developments coincided with the first attempt to bring all guano islands under the control of the colonial state, which in itself added further fuel to an already volatile political situation.

As Cape farming entered the 1880s the economic outlook continued to be decidedly bleak. To ensure a measure of food security, the colony settled into the mode of having to import three quarters of a million pounds worth of breadstuffs a year. The first year of the new decade also saw a steep decline in the sale of wine, brandy and dried fruit on the Kimberley market and a steep drop in wheat prices following another poor harvest season. Agricultural and other forms of credit also became scarce, following a range of insolvencies in the wake of the crash of the Cape brandy market and at a time that both the wheat and farming sectors were in serious need of credit for further expansion. Wine farmers needed it to "improve the quality of their wine" and to "diversify into deciduous fruit farming", whereas wheat farmers needed it to finance a programme of mechanisation. ${ }^{43}$ Both groups required additional capital to address the ongoing problem of declining soil quality; to mitigate the effects of natural disasters; and to overcome the constraints imposed by inadequate public transport. Collectively, these conditions forced the farming community to engage in constituency politics, with farmers demanding not only special state protection and official aid but also help against "merchants resisting protections under the banner of free trade". 44

\footnotetext{
${ }^{39}$ T.R.H. Davenport and C. Saunders, South Africa: A Modern History, 5th edition (Longman, London, 2000), p. 106.

${ }^{40}$ M. Tamarkin, Volk and Flock: Ecology, Identity and Politics among Cape Afrikaners in the Late Nineteenth Century (Unisa Press, Pretoria, 2010), p 92.

${ }^{41}$ Davenport and Saunders, South Africa: A Modern History, p 108.

${ }^{42}$ M.A.S. Grundlingh, "The Parliament of the Cape of Good Hope with Special Reference to Party Politics, 1872 to 1919", Archives Year Book for South African History (Government Printer, Pretoria, 1969), p 184.

${ }^{43}$ Giliomee, "Aspects of the Rise of Afrikaner Capital", p 69.

${ }^{44}$ Giliomee, "Aspects of the Rise of Afrikaner Capital", p 75.
} 
Leading the fight on behalf of Cape farmers in the colonial legislature was J.H.H. de Waal, the MPL for Piketberg and a member of the Afrikaner Bond. In 1885, De Waal demanded immediate state intervention. A farmer by trade, he stressed the need for higher import duties on imported grain and flour and the stabilisation of colonial farming for it to survive in a wholly capitalist and free market system. In addition, De Waal demanded the adoption of measures to ensure a supply of cheap labour to give the local industry a fighting chance and to ensure some measure of profitability. The colonial authorities, being supporters of free trade and enjoying the support of the English-speaking merchants and the electorate were, however, reluctant to act and in the process alienated the small groups of prosperous and progressive commercial farmers who were the strongest campaigners for beneficial change within the sector. ${ }^{45}$

The general agricultural situation continued to worsen throughout the $1880 \mathrm{~s}$ with a continued drop in wheat prices to the lowest level - from 12 shillings per bushel in 1881 to five shillings in 1888 - coupled with the outbreak of phylloxera in the vineyards of the Boland. As the phylloxera plague spread through the wine industry destroying everything in its path and generally demoralising farmers over a wide front, grain farmers watched with growing concern the possibility of the wheat price dropping below the psychological point of seven shillings and sixpence. Such an occurrence would ruin them financially. The common denominator in both cases was the state of the soil, which was central in the production process. Urgent intervention was therefore sorely needed.

In the absence of immediate government action, the company White, Ryan \& Co. sensed a business opportunity and in the year 1889 imported between 200 and 300 tons of complete compound fertiliser from Joseph Fison \& Co. in England. Upon its arrival in Cape Town a year later, 10 tons of "corn and hay fertiliser" were sold to a certain Mr Van Heerden, a farmer from the Malmesbury district. ${ }^{46}$ This started a whole new chapter in Cape agricultural history.

In the face of this crisis, the Sprigg government with its original policy of "positive government" which was premised on the principle that the interests of the Cape Colony should at all times be put first, finally acted. ${ }^{47}$ Departing from the premise that declining and poor soil quality was the main cause for poor harvests, on 2 July 1889, the Cape Legislative Assembly resolved in terms of Resolution 2 to place all guano islands under the direct control and management of the Department of Agriculture in order to provide "purchasers with a good article at a reasonable price, and this means encourage production, chiefly of grain, to a greater extent" to benefit colonial farming. ${ }^{48}$

45 Giliomee, "Aspects of the Rise of Afrikaner Capital", pp 68-69.

${ }^{46}$ Rosenthal, "The Story of Fison Albatross in South Africa", p 10.

47 Grundlingh, "The Parliament of the Cape of Good Hope", p 213.

${ }^{48} \mathrm{KAB}$, Cape of Good Hope (hereafter COGH), Votes and Proceedings of the Legislative Council, 2 July 1889. Resolution 2 reads as follows: "that in view of the increasing demands by 


\section{The establishment of the Cape Guano Agency, 1890}

Although the Cape Legislative Assembly's decision to establish full government control over the guano trade was taken by a majority decision, its implementation revealed deep-seated differences between key public representatives from the Eastern and the Western districts. These differences were rooted in years of distrust and a long-standing fear that once in power, the Boer/Afrikaner majority would advance ethnic interests rather than the general economic interests of the colony, and that this would be to the financial detriment of the British community. ${ }^{49}$ There were, however, also internal differences within these groupings, especially amongst nonparliamentarians. The latter group was firstly, concerned about government entering a relatively unknown field, and secondly, about the effect this decision would have on the operations of independent businessmen in the guano trade. Critically, the authorities also had to find an appropriate regime to organise the new undertaking. Resolving these issues was vital for the success of this venture.

During the debate in the Legislative Assembly, various questions were raised about operational efficiency, the effect of a government enterprise on private contractors, and the growing demands from farmers for free allocations or subsidised guano. For Sydney Twentyman Jones, the best route to low guano prices was through the achievement of operational efficiency and by keeping the overhead costs as low as possible. In his assessment, the colonial administration lacked the ability to work the guano islands economically and he was therefore sceptical about its chances of success. ${ }^{50}$ The better option therefore was to leave the industry in the hands of private entrepreneurs. A. Louw, the MLA for Malmesbury, although in support of government control of the industry, feared that a government operation would cause "hardship" and financial ruin to guano contractors who had traditionally serviced the farming sector. ${ }^{51} \mathrm{He}$ therefore supported the cause of these entrepreneurs and argued for their accommodation rather than exclusion. Offering a different view, Colonel Schermbrucker MLA, a representative from one of the Cape Town wards, cautioned that steps should be taken to prevent the establishment of a governmentcontrolled system creating a sense of entitlement and a demand for free guano amongst farmers in the future. ${ }^{52}$

Against this background, the colonial authorities established the Cape Guano Agency, to be managed by a guano agent appointed by the government. This

farmers for the "manure" called guano, this House is of the opinion that the guano islands should not be leased after the expiration of the several contracts or leases entered into, but that they should be placed under the direct control and management of the Agricultural Department, so as to provide purchasers with a good article at a reasonable price, and by this means encourage production, chiefly of grain, to a greater extent."

${ }^{49}$ Kirk, "The Cape Economy and the Expropriation of the Kat River Settlement", p 239.

${ }^{50} \mathrm{KAB}, \mathrm{AMP}$ PUBS, CCP, Debates and Proceedings of the House of Assembly (hereafter HA): Mr Jones, MLA, 2 July 1889, p 231.

51 KAB, AMP PUBS, CCP, HA: Thos Louw, MLA, 2 July 1889, p 231.

52 KAB, AMP PUBS, CCP, HA: Col. Schermbrucker, MLA, 2 July 1889, p 231. 
functionary was tasked with effect from June 1890 to manage all aspects of guano collection on the offshore islands on both the western and eastern coasts of the colony. Given the lack of knowledge within the existing colonial bureaucracy, the position was offered to Captain C.H. Jackson, a veteran of the guano trade. Based on the available evidence, Jackson subtly lobbied for the position for which he was willing to close down his own business. By his own admission, he accepted the position to derive "some income or benefit out of it". ${ }^{33}$ Service to farmers for whose benefit the Guano Agency was established in the first place was therefore only of secondary concern. This was further complicated by the terms under which Jackson was employed; over time, this became a major cause of conflict between the various stakeholders.

In accordance with a verbal agreement reached with the Department of Crown Lands and Public Works (DCLPW), Jackson was initially appointed for a two-year contract. His remuneration was based on commission on guano sales. In order to manage the islands on business lines, he was also granted full discretion in all matters. ${ }^{54}$ All salary expenses, inclusive of worker salaries, administrative costs and provisions incurred for the operations on the islands, could also be reclaimed from the colonial state. These service conditions were far removed from the standard rules applicable to employment in the colonial bureaucracy. The decision to tie Jackson's remuneration to the sale of guano implicitly meant that low prices would be prejudicial to his vested economic interests. This meant that the new system started off with certain inherent weaknesses which had the potential to undermine the strategic agenda on which the creation of the Guano Agency was based.

As he began to create the necessary infrastructure to provide a regular supply of guano to the farming community, Jackson used his wide discretionary powers to entrench certain profit generating and cost-saving mechanisms beneficial to his own economic interests. To keep operational costs within reasonable limits, he established a central guano depot in Cape Town with a capacity of 300 tons for the storage, weighing, mixing, sales and dispatch of guano. Furthermore, to ensure a continuous supply of guano, the system of maintaining a regular island workforce, established by private entrepreneurs over the years, was continued. To reduce the costs entailed in providing transport for guano purchases, a factor which was both crucial to the survival of the industry and potentially one of its main cost drivers, Jackson attempted to institutionalise a stipulation that buyers had to provide their own transport. In addition, analysis of the fertiliser, another potential cost driver that involved the services of an analytical chemist, was to be based on request and at the cost of the buyer. ${ }^{55}$

53 KAB, AMPT PUBS, CCP 1/2/2/1/48, SC. A.12- '97: Testimony of Captain C.H. Jackson, 1 and 9 June 1897, pp 15 and 38.

${ }^{54} \mathrm{KAB}$, AMPT PUBS, CCP 1/2/2/1/48, SC. A.12-'97: Testimony of Captain C.H. Jackson, 1 June, 1897, p 2.

${ }_{55} \mathrm{KAB}$, AMPT PUBS, CCP $1 / 2 / 1 / 82$, Ministerial Department of Crown Lands and Public Works: Memorandum on Working of the Guano Islands (G.55 -'91), 21 May 1891. 
Given the potential of these issues (that of transport in particular) to become a source of farmer dissatisfaction, Jackson was overruled by his superiors in the DCLPW and he was instructed to provide for the transportation of guano purchases by railway trucks at a price of $£ 8$ less $5 \%$ discount net cash as a normal service. This instruction affected not only his budget but also directly impacted on his commission. To overcome these constraints and to ensure the effectiveness of his profit-making arrangements, Jackson deliberately cultivated markets in neighbouring Lourenço Marques, Transvaal and the Orange Free State. In addition, he appointed a marketing agent in London to exploit the long established European and British market. This action was in direct contravention of the accepted practice of working through the general agents in London or through officially appointed Crown agents. ${ }^{56}$ Export activity, according to Gorman, tends to mobilise formerly marginalised sections of the population to enter the political system as competitors. ${ }^{57}$ This is precisely what happened in this case and the export of guano to neighbouring territories became an immediate bone of contention with the Cape farming sector.

\section{Fair access, regional interests and the agent's commission}

With the activation of the Cape Guano Agency in 1892, the central depot in Cape Town was flooded with orders from all regions of the colony. The majority came from the principal wheat growing areas such as the Swartland, Breede River Valley and Southern Cape regions.58 Among the orders received were requests from individuals as well as organised groups such as the Knysna Political Association (KPA) and the Lower Albany Farmers' Association (LAFA) in the Eastern Province. ${ }^{59}$ The KPA in particular, supported by the local Divisional Council, proposed the establishment of a small guano depot in the Southern Cape region with a view to servicing local farmers. ${ }^{60}$ Farmers in the Western districts, given their proximity to the central depot and immediate access to parliamentarians in Cape Town, were unashamedly ready to exploit all possible benefits associated with the new dispensation. Although the Eastern districts were at a disadvantage due to their distance from the centre, they were no less determined to get their fair share. From the outset they insisted on paying the same price as buyers in the Western Province. ${ }^{61}$ With the new management of the guano industry still in its first collection season, it lacked

\footnotetext{
${ }^{56}$ A. Porter, "Britain, the Cape Colony, and Natal, 1870-1914: Capital, Shipping and the Imperial Connexion", The Economic History Review, 34, 4, November 1981, p 558.

${ }^{57}$ S.M. Gorman, "The State, Elite, and Export in Nineteenth-Century Peru: Towards an Alternative Re-interpretation of Political Change", Journal of Inter American Studies and World Affairs, 21, 3, August 1979, p 412.

${ }^{58}$ KAB, Department of Agriculture (hereafter AGR) 153, 667: S. Du Toit - A. Fischer, 2 May 1892.

${ }^{59} \mathrm{KAB}, \mathrm{AGR}, 231$, 2153: S. Lansdell - Secretary of Lands, Mines and Agriculture, 11 November 1892.

${ }^{60} \mathrm{KAB}$, AGR, 231, 2153: W. Mason, Secretary of the Knysna Political Association - Assistant Commissioner of Crown Lands and Public Works, 23 June 1891.

${ }^{61} \mathrm{KAB}, \mathrm{AGR}, 231,2153$ : S. Lansdell - Secretary of Lands, Mines and Agriculture, 11 November 1892.
} 
sufficient stock and therefore struggled to set appropriate prices. This meant that most of the early orders had to be declined. ${ }^{62}$

Distance from the centre and the resultant high transport costs, which most succinctly demonstrated the divide between the different regions of the colony, soon became one of the most contention issues of the struggle for equal access between the Eastern and Western districts on the one hand, and the guano agent on the other. Given the poor state of roads, the railway department recommended shipping guano to the Eastern districts via Port Alfred and the Kowie River railway stations as the best option. ${ }^{63}$ At the time, the lowest fee for transporting large volumes of guano to Lower Albany in the Eastern Cape was £115.10s. ${ }^{64}$ Against this background, the proposal of the Knysna Divisional Council for the establishment of a satellite depot to service the broader southeastern region thus represented a meaningful compromise. However, this had cost implications which could negatively impact on the final commission received by the guano agent.

Given his vested interests, Jackson was opposed to the Knysna proposal and suggested provisioning the south-eastern region from the St. Croix and Bird islands along the Mossel Bay and Port Elizabeth coasts. ${ }^{65}$ However, the product from these islands was of an inferior quality and differed substantially from the uniform and balanced quality mix supplied by the central depot in Cape Town. The Jackson proposal was thus little more than a cynical attempt at cost cutting to the disadvantage of the agricultural community. Similarly, he declined the LAFA's request for equitable provision and left them on their own to conduct negotiations on concessionary rail tariffs with the railway department for the transportation of their guano purchases. ${ }^{66}$ Throughout this imbroglio, there was no effort from either the farmers in the Western districts or the colonial authorities to actively align themselves with the concerns of their Eastern counterparts, or indeed to question Jackson's decisions.

In addition to the supply logistics, the cost of guano remained a perennial issue. At the time of the establishment of the guano administration, the sales price was set at $£ 7.12$ s per ton and was calculated based on the average local price of $£ 8$ minus $5 \%$ discount for cash. ${ }^{67}$ This was simply too expensive for most farmers and as a result W. Basson MLA gave notice in June 1891 of his intention to request parliament to consider a price reduction and to instruct the guano agent to provide all sellers with an analysis of their purchases. The commissioner of Crown Land and

${ }^{62} \mathrm{KAB}$, AGR, 231, 2153: Assistant Commissioner of Crown Lands and Public Works - W. Mason, Secretary of the Knysna Political Association, 9 July 1891.

${ }^{63} \mathrm{KAB}, \mathrm{AGR}, 231$, 141: Assistant General Manager - Secretary of Public Works, 1 December 1892.

${ }^{64} \mathrm{KAB}, \mathrm{AGR}, 231,141$ : Commissioner of Crown Lands and Public Works - Assistant General Manager of Railways, 29 November 1892.

${ }^{65} \mathrm{KAB}, \mathrm{AGR}, 231$, 2153: Capt. C.H. Jackson - Assistant Commissioner, 9 July 1891.

${ }^{66} \mathrm{KAB}, \mathrm{AGR}, 231,2153$ : C.H. Jackson - Assistant Commissioner, 17 November 1892.

${ }^{67} \mathrm{KAB}$, AMPT PUBS, CCP 1/2/2/1/48, SC A.12-'97: Testimony of Capt. C.H. Jackson, 1 June 1897, pp 4-5. 
Public Works, McNaughton, took issue with this suggestion and strenuously opposed universal analysis and a reduction of the existing price. Universal analysis in his view (and by implication that of Jackson) would not bring about lower prices, but would generate additional costs. ${ }^{68}$ Furthermore, he argued that the product was already 50 shillings below market value and further reductions would seriously compromise the profitability of the industry.${ }^{69}$ Over time this became the standard response to any demand for a lowering of the guano price and served Jackson's economic agenda; he preferred stable prices.

Notwithstanding his personal conduct, in general terms Jackson proved an able administrator. In May 1891, after one year of operations, the Guano Agency reported a net profit of $£ 2973.12 \mathrm{s.50d}$ for the sale of guano, penguin eggs and seal skins. ${ }^{70}$ Based on this performance, he was offered a formal, written contract on 21 March 1892. The new contract, in comparison to its predecessor, included a great deal more specific detail that was aimed at better serving the needs of the farming community. Among the new prescribed duties of the guano agent were that he should: make provision for credit and discounts of $5 \%$ on cash sales (rail freight included); dispatch the guano by rail to a station closest to the buyer; that a cash sale price was to be fixed at $€ 7.12 \mathrm{~s} .5 \mathrm{~d}$ per ton; and that a compulsory provision of chemical analysis of purchases in line with the European standard should be made upon request by the client.

It is clear that the new contract was based on an improved understanding of the actual operations of the guano trade and from this perspective it was unashamedly pro-agriculture. However, this is not to suggest that these changes came about as a result of feelings of benevolence on the part of the colonial state. Instead they were the result of persistent lobbying - agitation that the colonial authorities could only ignore at their peril. The fact that the contract made provision for payment of commission to Jackson on a sliding scale is also indicative of a realisation among the decision makers that the new stipulations would negatively impact on his annual commission earnings and that this situation had to be mitigated to some extent. By implication, these measures also served as an incentive for the guano agent to maintain a high level of production and sales. ${ }^{71}$ In other words there was still enough space for Jackson to extract personal profit through his role as a government employee.

However, Jackson resented the changes in the administrative regime. The new conditions not only militated against his attempts to outperform the remaining guano island leaseholders, but also complicated his efforts to get rid of excess guano in

\footnotetext{
${ }^{68} \mathrm{KAB}$, AGR, 231, 2153: McNaughton Report, 25 June 1891.

${ }^{69} \mathrm{KAB}$, AGR, 231, 2153: Capt. C.H. Jackson - Assistant Commissioner of Public Works, 21 December 1892.

${ }^{70} \mathrm{KAB}$, AMPT PUBS, CCP 1/2/1/82, G 55-'91, p 3.

${ }^{71} \mathrm{KAB}$, AMPT PUBS, CCP 1/2/2/1/48, SC A.12-'97: Testimony of C. Currie, 4 June1897, p 26.
} 
storage at various points of retail within the colony. ${ }^{72}$ The colonial authorities, however, firmly insisted on total compliance with official orders for the coming season.

Following an extremely wet season in 1892/3, guano volumes were low and of indifferent quality. In these conditions of relative scarcity, the farming sector demanded not only an immediate reduction in the existing price but also agitated for an immediate termination of guano exports. ${ }^{73}$ In the light of its recent reduction, the colonial government refused to accede to the demand. This left the farmers greatly dissatisfied and sparked a larger upheaval centred on Jackson's administration spearheaded by Swartland farmers.

At a meeting held in late 1892 in Malmesbury, protesting farmers repeated their demand for lower prices; they wanted them pegged at $£ 6$ per ton. ${ }^{74}$ Led by a group of high-profile farmer-politicians from the Cape Colony's principal wheat and wine growing areas, the gathering listed a significant number of demands. ${ }^{75}$ Among these were calls for the allowance of credit sales; the replacement of private guano sellers by government guano-sellers; the use of convicts as guano labour as a costcutting measure; and significantly, the termination of the guano commission system. ${ }^{76}$ These demands, although principally driven by the Western districts constituency, were universal in nature and non-sectarian. However, they still excluded pastoral farmers who were equally in need of some form of government subsidisation. This notwithstanding, given the involvement of a significant group of legislators with political clout in this action, the executive had no option but to take note and respond accordingly.

In January 1893 a delegation representing the protestors met an official government delegation led by Sir Pieter Faure. On this occasion, the demand for a further reduction of the guano price was formally tabled. The Faure delegation was, however, unable to order an immediate decrease since the existing price had been approved by parliament and only the legislature could reverse the situation. Faure therefore undertook to propose a price reduction during the 1895 sitting of the legislature when the Ichaboe lease expired and the island returned to full government control. This did not satisfy the farmers because relegating the issue to the future in a situation of agricultural and economic uncertainty would not necessarily bring better results. As a result Louw, the MLA for Malmesbury called for a selling price of $£ 5$ per

\footnotetext{
$72 \mathrm{KAB}$, AMPT PUBS, CCP 1/2/1/82; Memorandum on the Working of the Guano Islands (G.55-'92), p 1.

${ }^{73} \mathrm{KAB}$, AMPT PUBS, CCP 1/2/1/85: G.58 -'93.

74 "De Guano Kwestie en Deputasie van Malmesbury en Omstreken", De Zuid Afrikaan, 17 January 1893.

75 Amongst the parliamentarians involved in the protest were A. Louw (MLA for Malmesbury), D. de Waal (MLA for Cape Town), Z. de Villiers (MLA for Paarl), J. van der Spuy (MLA for Koeberg) and S. Walters (MLA for Piketberg).

76 "Guano", Ons Land, 17 January 1893.
} 
ton, much to the ire of the guano agent who in a very disparaging manner labelled this demand as having "no weight" except that it served to "mislead the more ignorant". ${ }^{77}$

The phenomenon of the activist parliamentarian or farmer-politicians was not a new one in Cape colonial history. The increasingly tight alliance displayed between farmers and their public representatives and the dexterous deployment of both extraparliamentary tactics (petitions and delegations) and parliamentary means (special investigation commissions or Select Committee hearings) to put pressure on the colonial government, had been used successfully in the past in a variety of protests including that against the wine excise duty (1878); the rural enclosure movement (1865 to 1910); and by the Anti-Scab Movement (1894). ${ }^{78}$ Farmers were thus under no illusion about the potential value of collective action as a means of achieving strategic goals.

Eastern Province farmers, perturbed by the continued marginalisation of their issues and in the wake of the action by those in the Western districts, forcibly foregrounded their issues in June 1893. In addition to repeating the demand for the lowering of the guano price they demanded the equitable distribution of the product to all farmers in the colony. In this regard, they mandated their MLA, J. Trower, to raise the matter during the sitting of the House of Assembly on 4 July 1893 and to demand "that the government be requested to allow guano to be delivered at any railway station on the Colonial system of railways at actual cost of carriage". ${ }^{79}$ This convergence of thought and action of the two regions raised the possibility of future united farmer action based on a common agenda.

When the matters of the Eastern districts were raised in parliament, the assistant commissioner of Crown Lands reiterated the department's standard position, namely that a price reduction was not feasible and that the demand could not be met. ${ }^{80} \mathrm{~A}$ number of politically provocative statements from Jackson did not help matters. His stated view that the Western Cape market was his primary responsibility was particularly galling. ${ }^{81}$ Furthermore, he argued that haulage had nothing to do with the price of guano and suggested that the real problem was simply one of the Eastern districts farmers "living so many miles from Cape Town". ${ }^{82}$ In addition, he suggested in a letter to his superiors that the issues raised by the farmers were "inconsequential" and that claims of low guano quality was an issue "not worth mentioning". 83 The resultant refusal to lower the rates for farmers in the Eastern Province whilst the demands of their Western counterparts were seemingly nearly

\footnotetext{
77 KAB, AGR, 231, 2153: Capt. C.H. Jackson - Laing, 19 February 1884.

${ }_{78}$ Tamarkin, Volk and Flock, pp 145-146.

${ }^{79} \mathrm{KAB}, \mathrm{AGR}, 231$, 2153: Secretary of Lands, Mines and Agriculture - Assistant Commissioner of Railways and Public Works, 5 June 1893 (emphasis added).

${ }^{80} \mathrm{KAB}, \mathrm{AGR}, 231$, 2153: Assistant Commissioner of Crown Lands and Public Works Secretary of Lands, Mines and Agriculture, 5 June 1893.

${ }^{81} \mathrm{KAB}, \mathrm{AGR}, 231$, 2153: Chief Traffic Manager - Secretary of Public Works, 30 August 1894.

${ }^{82}$ KAB, AMPT PUBS, CCP 1/2/2/1/48, SC A.12-'97: Testimony of Capt. C.H. Jackson, 1 June 1897, p 13.

${ }^{83}$ KAB, AGR, 231, 2153: Secretary of Public Works - N. Janusch, 3 February 1893.
} 
always met, left Cape farmers even more divided and put further strain on the relationship between the colonial government and farmers. This duly became a stimulus for further organised action.

In the public mind there was a tendency of certain sections of the colonial administration to side with the guano agent during these disputes. This not only exacerbated tensions but also eroded trust in the colonial authorities. Ironically, the relationship between Jackson and his counterparts in other colonial departments was equally poor and served as the spark for the continuation of protests. Accustomed to getting his own way, Jackson had little regard for the work of others and the impact of his actions on the end-user. In addition to bad faith towards him in the Department of Agriculture, he also alienated the Colonial Railways over the issue of appropriate times for the delivery of guano. ${ }^{84}$ It therefore came as no surprise when conflict erupted yet again in December 1893.

The gradual reduction of the guano price and variations in the quality of the product due to wet winter seasons, directly affected sales and implicitly impacted on Jackson's commission. Although the situation improved somewhat after June 1891 with the addition of the islands in Saldanha Bay, Hout Bay and False Bay, which brought the number of islands and rocks under government control to thirteen, growth in Jackson's direct benefits from the enterprise was slow. To boost his income, Jackson introduced a guano buyers list, ostensibly as part of his administrative responsibilities to better organise his service to clients. Farmers not on the list would be forced to purchase either from third parties or from the Guano Agency at a nonregulated price, or to use alternative fertilisers. Both these options had cost implications for interested buyers. When the final buyers list closed on 1 January 1894, it created a groundswell of dissatisfaction. ${ }^{85}$ Since this measure was universally discriminatory and threatened to reverse the gains made by farmers, renewed mobilisation followed. Farmers also correctly identified the implications of a closed list, namely the possibility of price manipulation by unscrupulous businessmen and others, including the guano agent. Once again with the support of farmer-politicians they protested against the short notice and the equally poor advertising of the new measure. In response to this campaign, the colonial authorities extended the application period and ordered the issuing of new notices throughout the colony. They also prohibited the use of private guano intermediaries as a regulation to prevent price manipulation. ${ }^{86}$ However, despite winning these concessions, farmers were still far from being united.

${ }^{84} \mathrm{KAB}, \mathrm{AGR}, 231,2153$ : Assistant General Manager - Secretary for Lands, Mines and Agriculture, 2 August 1893.

$85 \mathrm{KAB}, \mathrm{AGR}, 231,2153$ : C.H. Jackson - Office of the Commissioner of Public Works, 8 December 1893.

${ }^{86} \mathrm{KAB}, \mathrm{AGR}, 231$, 2153: Report of N. Janusch - Secretary for Public Works, 25 December 1893. 


\section{Protest, parliamentary commissions and positional change}

Because the Western Province farmers were still the main beneficiaries of the concessions gained through the various delegations, Eastern Province parliamentary representatives questioned these measures and the actions that disadvantaged farmers in their constituencies. Captain E.Y. Brabant severely criticised the discounted sale of guano to Western district farmers, which he regarded as not only blatantly unfair but also an unjustifiable form of cross subsidisation. ${ }^{87}$ In this regard, he echoed Jackson's sentiments and description of the situation as tantamount to government giving commercial farmers a present for no apparent reason. ${ }^{88}$ Brabant demanded that the authorities at least consider reducing transport charges to accommodate Eastern farmers, and that the export of guano to foreign states such as the Transvaal and Orange Free State, who were receiving the product at the same rate as colonial farmers, should be terminated. ${ }^{89}$ In his opinion guano had to be reserved for the exclusive use of Cape farmers. However, continued divisions within the legislature delayed the final resolution of the matter.

By January 1895, under pressure from continued agitation of farmerpoliticians and their constituencies, the colonial authorities publicised their intention of granting another price reduction. In terms of Government Notice No. 45, the price of ordinary guano was to be reduced to between $£ 6.10$ s per ton of 2000 pounds or 13 shillings per bag of 200 pounds; and that of rock guano to $€ 6.17 \mathrm{~s}$ per ton of 2000 pounds or $13 \mathrm{~s} .9 \mathrm{~d}$ per bag of 200 pounds. ${ }^{90}$ The guano agent consistent with his previous position, did not support this measure and refused to implement it. This resulted in another protest to parliament and the DCLPW in March 1895. Governor Gordon Sprigg had no option other than to intervene and ordered a price reduction backdated to 1 January 1895. In addition, all buyers who formerly bought stocks at the old price were grant a refund and an immediate despatch of all orders to their agreed destinations. The repayment of the first batch of remissions cost Jackson $£ 4384.16$ s, which took a significant bite from his past and future commission. ${ }^{91}$ To prevent possible manipulation of this process, all the repayment was handled by the offices of the various civil commissioners. ${ }^{92}$ For the first time these actions moved beyond mere tinkering with Jackson's system.

In a further act of open defiance, Jackson continued to sell guano at the old price of $£ 7.1 \mathrm{~s} .5 \mathrm{~d}$ and calculated his commission on the same basis. This action was justified on the basis of: "I went in with the idea of deriving some income or benefit

87 "Guano", Cape Times, 14 June 1894.

${ }^{88} \mathrm{KAB}, \mathrm{AMPT}$ PUBS, CCP 1/2/2/1/48, SC, A.12-'97: Testimony of Captain C.H. Jackson, 1 June 1897, p 7.

${ }^{89} \mathrm{KAB}$, AMP PUBS, CCP, HA: E.Y. Brabant, MLA; Debates and Proceedings of the House of Assembly, 13 June 1895, p 263.

${ }^{90} \mathrm{KAB}, \mathrm{AGR}, 231,2153$ : Under Secretary for Agriculture - Assistant Treasurer, 5 February 1895.

${ }^{91} \mathrm{KAB}$, AMPT PUBS, CCP 1/2/1/90: Memorandum on the Working of the Guano Islands (G.66-'94), pp 1-2.

$92 \mathrm{KAB}, \mathrm{AGR}, 231,2153:$ Treasury to Under Secretary for Agriculture, 1 March 1895. 
out of it. I would not have gone into the undertaking otherwise." 93 He therefore accused the colonial government of breach of contract since they had excluded Ichaboe from his contract. ${ }^{44}$ While this spat between the authorities and their functionary continued, farmers persisted with their demands that Sprigg's order be fully implemented. Through their parliamentary representatives, they pressed for a commission to investigate the guano administration system in general and the position of the guano agent in particular. As an act of protest some of those with the necessary means resorted to buying imported and locally produced chemical fertilisers sold by the likes of White, Ryan \& Co., who had established South Africa's first mixing facility in Kuils River. ${ }^{95}$ Other brands than the locally produced Oskop fertiliser were imported products such as Fison fertiliser which was sold by Chemical Union Ltd., Fison \& Co.'s local agent. ${ }^{96}$

The threat of irreparable damage to the industry occupied the minds of legislators for a significant time. By way of a solution, J.M. Peacock (MPL) suggested exporting local guano to England in exchange for importing chemical fertiliser. ${ }^{97}$ Since the majority of farmers already struggled to pay cash for their purchases this option failed to find any favour. Furthermore, the commissioner for Public Works deemed the export/import option as financially risky because guano was deemed a state asset with a certain monetary value. Since it represented trust money it was not to be placed at risked..$^{98}$ D.P. van den Heever and F.J. van Eeden, two other legislators, were adamant that guano should serve the nation and therefore had to be sold as cheaply as possible as a means to develop the country. ${ }^{99}$ There were fears that in the event of parliament failing to advance the interests of farmers, it would be portrayed as an obstructionist and non-progressive institution. ${ }^{100}$ There was, however, consensus among legislators that Jackson's contract should be terminated in the interest of the farming sector. This was duly put into effect in June 1896 - a move which brought the age of the "guanopreneur-in-government" officially to an end.

Following the departure of Jackson, a formal commission of inquiry into the workings of the guano island administration under the chairmanship of the MLA for Malmesbury, A. Louw, was initiated on 28 May 1897. This commission included parliamentarians from both the Eastern and Western provinces of the colony and aimed to balance the regional interests of both regions. After considering testimony

\footnotetext{
${ }^{93}$ KAB, AMPT PUBS, CCP 1/2/2/1/48, SC A.12-'97: Testimony of Captain C.H. Jackson, 9 June $1897, \mathrm{p} 38$.

${ }^{94} \mathrm{KAB}, \mathrm{AMPT}$ PUBS, CCP 1/2/2/1/48, SC A.12-'97: Testimony of C.H. Jackson, 1 June 1897, pp 14-15.

${ }_{95} \mathrm{KAB}$, AMPT PUBS, CCP 1/2/2/1/53, SC A.30-'99: Testimony of Paulus Eksteen, 21 September 1899, p 20.

${ }_{96}$ Rosenthal, "The Story of Fison Albatross in South Africa", p 10.

${ }^{97} \mathrm{KAB}, \mathrm{AMP}$ PUBS, CCP: Debates and Proceedings of the Legislative Council (hereafter LC): J.M. Peacock, MLC, 23 June 1896, p 192.

${ }_{98}$ Commissioner for Public Works; Debates and Proceedings of the Legislative Council, 23 June 1896, p 193.

${ }_{99}$ KAB, AMP PUBS, CCP, LC: D.P. van den Heever, MLC, 23 June 1896, p 194.

100 KAB, AMP PUBS, CCP, LC: F.J. van Eeden, MLC, 23 June 1896, p 194.
} 
from a range of stakeholders, the commission recommended the maintenance of the existing administrative system and took steps to ensure the equitable division and delivery of guano at all the colony's ports. ${ }^{101}$ This recommendation was an important victory for farmers in the Eastern Province. However, the commission could not reach unanimity over other critical aspects of the local trade. Frost and Brabant, although partial to the interests of the Eastern farming sector, were vocal supporters of the principles of free trade. In a minority report they called for guano sales on the open market with no government intervention, or alternatively for commission based on the original price.102 Louw and Marais, the acknowledge spokespersons for the Western farming lobby, in a minority report of their own, recommended that a uniform selling price be implemented; commission be based on a net price of $£ 6.10$ s.5d; that an amended commission or fixed salary be paid to the guano agent; and that the industry be converted into a fully state-run operation. In the end, this position prevailed and became the official government policy.

Following the conclusion of the commission's investigations, the guano islands were placed under the Guano Island Division (GID), a new sub-department of the Department of Agriculture (DOA) with effect from 1 July 1898. Notwithstanding the adverse findings about Jackson's conduct, he was reappointed in the renamed position of the superintendent of the government's guano islands. This was particularly ironic since his former assistant, Captain John Spence whom Jackson appointed during his former tenure as guano agent, was equally experienced in the management of the system. Jackson's re-appointment pointed to the existence of strong political support for the individual amongst parliamentarians who favoured a free trade policy. Farmer-politicians such as Marais, De Vos and Hofmeyr supported the unrestricted provision of farmers with a product that was affordable and of a high quality so as to advance grain farming. As previously indicated, the sentiments of men such as Jones, Louw and Schermbrucker, were closer to those of Jackson since they supported the sale of guano on the open market and the proactive prevention of a sense of entitlement amongst farmers. Another critical voice was that of A. Wilmot who argued consistently that all farmers - not only those involved in grain farming should benefit from a beneficial guano price regime. ${ }^{103}$ Jackson's relationship with his new department and the farming sector, however, was critical for the further development of the local trade.

\section{The obstructionist superintendent, 1898-1904}

Jackson's new employment as the superintendent of the Guano Islands Division (GID) differed significantly from his former position as government guano agent. Although his position was fully bureaucratised, he still retained certain discretionary powers. ${ }^{104} \mathrm{~A}$ significant change as far as the farmers were concerned was the formal

${ }^{101} \mathrm{KAB}$, AMPT PUBS, CCP 1/2/2/1/48: SC. A.12-'97, p vi.

102 KAB, AMPT PUBS, CCP 2/2/1/76: SC.10-'98, p 10.

${ }_{103} \mathrm{KAB}$, COGH: Proceedings of the Legislative Council, 23 June 1896, p 194.

${ }^{104}$ KAB, AMPT PUBS, CCP $1 / 2 / 2 / 1 / 53$, SC. A.30-'99: Under Secretary for Agriculture Superintendent of the Government Guano Islands, 26 May 1899, Annexure (E) to Report. 
provision for the extension of credit to those purchasers who were unable to pay cash. However, this discretion, as well as the acceptance of cheques as a means of payment, was never exercised under the new dispensation following an increase in the number of dishonoured cheques. Without any consultation with his superiors Jackson maintained a system of only accepting cash sales because it was less of an administrative problem. ${ }^{105}$ Since a significant number of buyers preferred cheque payments, they contested Jackson's right to insist on cash. Farmers appealed to their representatives in the colonial parliament and demanded a change in the system. Jackson remained recalcitrant. In addition to an unhelpful attitude towards the farmers on several occasions he circumvented official procedures by refusing to certify particular transaction documentation that had to be submitted for audit purposes. ${ }^{106}$ In another act of open defiance, he also ignored the explicit rule that prohibited the export of guano without prior permission from the agent-general by selling cargo to Bechuanaland and Rhodesia. ${ }^{107}$ This was particularly cynical given the growing local agitation for the maintenance of a guano reserve and lower prices. This combination of factors led to Jackson's suspension and his service was terminated on 30 June 1899. Parliament also ordered a further enquiry into the operations of the guano administrative system with the instruction to pay particular attention to further price reductions, expenditure, customer service and the position of the superintendent. ${ }^{108}$

Although the proceedings of the investigative committee were interrupted by the looming war between Britain and the Boer republics of the Transvaal and Orange Free State, a formal report was produced and tabled in parliament before its last sitting in 1899. The committee found that the guano island service was indeed dysfunctional and that its management left much to be desired. In addition to total non-compliance with regard to standard audit regulations, serious weaknesses were identified in the marketing and sales system as a result of Jackson's defiant use of an overseas-based private agent. One of the key recommendations was therefore to replace the London agent with an agent appointed by the government. ${ }^{109}$ However, the outbreak of the Anglo-Boer War (South African War) of 1899-1902, delayed the implementation of most of its key recommendations. Reluctant to place the Guano Island Division in new hands at such a critical time, an ironic twist of events resulted in Jackson's re-appointment despite the severe criticism of his highly questionable management style. He continued in his post as superintendent until he passed away in 1904. The frustrations of the farmers had to wait until after the conclusion of the South African War and the signing of the Treaty of Vereeniging in 1902, before they could be addressed.

105 KAB, AMPT PUBS, CCP, HA: Honourable Heroldt, MLA, 19 September 1899, p 493.

106 KAB, AMPT PUBS, CCP, HA: Honourable Beyers, MLA, 12 September 1899, p 440.

${ }^{107} \mathrm{KAB}$, AMPT PUBS, CCP, $1 / 2 / 2 / 1 / 53$, SC. A.30-'99: Testimony of K. Anderson, 26 September, 1899, p 37.

${ }_{108}$ KAB, AMPT PUBS, CCP, HA: Honourable D.J. Marais, MLA, 12 September 1899, p 439.

${ }^{109} \mathrm{KAB}$, AMPT PUBS, CCP 1/2/2/1/53: Report of the Select Committee (SC) on the Guano Islands (A.30-'99). 


\section{War, depots and new quality standards, 1899-1910}

The South African War (1899-1902) severely disrupted the guano supply system. As a result of limited storage facilities under war conditions, an adequate reserve could not be established at the Cape Town depot. Reserve guano therefore had to be kept on the islands. The commandeering of small sea craft for the transport of soldiers and provisions and new restrictions on coastal shipping and access control at most harbours, made the transportation of guano from the source to the distribution point in Cape Town a slow and irregular affair. In addition, overland transport became equally difficult because of the rail track blockage by the warring parties. A general shortage of rail carriages and trucks also added to the existing difficulties. On the labour front, the guano trade suffered serious staff shortages because it could not compete with the higher salaries paid by the military. ${ }^{110}$ These constraints not only caused long delays in product delivery but also heightened the frustrations amongst its customers.

Following the conclusion of the war, the colonial authorities set up a system of guano depots located at selected railway stations in the heart of the Cape's wheat growing areas of the Overberg and Swartland districts to aid the farming sector. Depots were established at towns such as Malmesbury, Kalbaskraal, Mooreesburg, Piketberg (Swartland), Worcester, and Caledon (Overberg). To supply the wheat and vine growers in the north-western part of the colony and the wine-growing areas outside Cape Town, a number of dedicated guano stores were opened in the Boland (Paarl) and the Elephant's River Valley (Clanwilliam). Station masters were assigned the responsibility of supervising the sale as well as the dispatch of guano and were paid an additional allowance to compensate for the extra tasks. To ensure uniformity in the system, all guano orders had to be placed at the various depots before being transmitted to the central depot in Cape Town, from where the correct load was despatched by railway carriage to the particular destination where the order had originated. The buyer was then able to collect the fertiliser he had ordered from the station closest to his home or farm. This measure went a long way towards addressing some of the longstanding grievances of farmers in the Western Province. However, the system continued to discriminate against those in the Eastern Province who were denied the same advantages. The deficiencies of the guano management system therefore contributed towards complicating the restoration of group relations in the post-war reconstruction era. Furthermore, the issue of pricing and Jackson's opposition to the guano depot system remained contentious issues.

Consistent with his past behaviour, Jackson opposed the new depot system. He particularly questioned its effectiveness and given the seasonal nature of the demand for guano and a planned expansion of storage space at the Cape Town store, he argued that the depots were an unnecessary expenditure that in due course they

$110 \mathrm{KAB}$, AMPT PUBS, CCP 1/2/1/121: Report of the Superintendent of the Government Guano Islands, Year 1902 (G.17-1903). 
would become obsolete. ${ }^{111}$ However, these plans were not realised by the time of his death in 1904 when John Spence was appointed as the new superintendent. Guano depots therefore remained an integral part of the Cape's agricultural landscape for a significant period of time.

The elimination of distance in supply, however, did not stop the continued agitation for price reductions. In its response on 1 January 1906, the colonial government decided to reduce the guano price to $£ 5$ per ton in addition to providing free rail transport to any station within the boundaries of the colony. ${ }^{112}$ This decision formally established supply equity to all farmers irrespective of their geographical location. In addition, in 1907 the authorities decided to institute a new commission of inquiry into the guano trade and the depot system to map their long-term plans for the sector.

The repeated appointment of commissions of inquiry creates the impression of a government lacking a coherent strategy. However, a close analysis of the debates within the colonial legislature suggests that the Cape authorities found commissions to be good tools to achieve political compromise between divergent interest groups. This was particularly important since a significant number of public representatives were farmers in their own right and they, like their counterparts with a commercial background, acted as defenders of their class interests. Commissions offered both groups a platform for engagement about the twin issues of lower prices, the extent of state involvement and the balancing of the two issues in the interests of free-trade.

The commission of inquiry under the chairmanship of James Searle began its work on 24 September 1906. Its brief, among other things, included investigating the general administration and management of the guano trade (such as depots, price, product standards, chemical fertilisers, etc.) and the investigation of the effect of the personnel structure and administrative deficiencies on the price structure of guano. ${ }^{113}$

Given the recurrence of the same contentious issues, the commission found that most of the original administrative deficiencies identified by previous commissions of inquiry still existed and therefore affected the product price adversely. It also revealed the increasing popularity of chemical fertilisers and their potential to displace natural fertilisers (such as guano) within the foreseeable future. Proposals were therefore made to ensure a uniform guano standard as well as the issuance of certificates of analysis to assist farmers in making informed decisions. ${ }^{114}$ The commission also recommended the closure of certain guano depots with the

${ }^{111} \mathrm{KAB}, \mathrm{AMPT}$ PUBS, CCP 1/2/1/126: Report of the Superintendent of the Government Guano Islands, Year 1903 (G.50-1904).

$112 \mathrm{KAB}$, AMPT PUBS, CCP 1/2/1/142: Report of the Superintendent of the Government Guano Islands, Year 1907 (G.33-1907).

${ }^{113}$ KAB, COGH: Testimony of J.N. Jack, Guano Island Commission, 26 September 1906, pp 4350.

114 KAB, COGH: Testimony of J.N. Jack, Guano Island Commission, 26th September 1906, p 44. 
exception of those located close to guano islands or rocks in the Western and Eastern Province. This report thus provided the colonial authorities with a sound basis on which to structure an industry that was both profitable and sustainable. The real test, however, was to be found in its formal implementation.

As a direct result of the commission's work, on 5 July 1907 the colonial legislature published a draft bill to amend the Sale of Food and Drugs and Seeds Act, No. 5 of 1890 in order to provide for the regulation and sale of guano and other fertilisers. ${ }^{115}$ This bill inter alia proposed the appointment of chemical analysts; trademark and product type registration; quality guarantees; the prevention of price manipulation; and regular analyses. Furthermore provision was made to impose penalties for breaches of the law and annual reporting to parliament was made compulsory. ${ }^{116}$ These stipulations were a clear indication that the farming community had finally won the fight and that the colonial authorities had learnt the administrative and political lessons of the preceding 64 years. On 17 September 1907, with the promulgation of the Act to Regulate the Sale of Fertilisers, Farm Foods, Seeds and Pest Remedies, No. 20 of 1907, a new era was inaugurated in the Cape guano trade.

\section{Conclusion}

The struggle by Cape farmers to gain ready access to guano fertiliser is a critical part of the history of the commercialisation of local agriculture. Although initially divided along language and ideological lines, the convergence of their economic interests and reaching clarity on their common commercial objectives was imperative. There had to be an improved understanding of the potential role of fertiliser in their enterprise and this united the disparate groups in the Western and Eastern districts in their endeavours to obtain subsidised guano. By using their access to particular political formations and public representatives, they forced both the newly established Department of Agriculture and the fledgling Cape legislature to streamline their systems and to keep their political representatives in touch with the concerns of the electorate. The fight between Jackson (a state official who acted like a "guanopreneur") and his employers, represented the last stand of the guanopreneurs against the full appropriation of guano income by the colonial state. Jackson's death and his replacement by Spence brought the farmers' struggle closer to its conclusion. The institution of lower prices, a system of decentralised depots, statutory quality standards and the legislative protection of seabirds, all of which subsequently followed, therefore represent the triumph of the Cape farmers over the export orientated business sector.

$115 \mathrm{KAB}, \mathrm{COGH}$ : Proceedings of the House of Assembly, 1907, p 83.

116 KAB, Cape of Good Hope Government Gazette, 5 July 1907, pp 53-56. 